\title{
Factors Influencing the Usefulness of Peer Review towards EFL Learners' Writing Performance
}

\author{
P A Tyas ${ }^{1}$ and M Safitri ${ }^{2}$ \\ ${ }^{1}$ English Education, Universitas Brawijaya, Malang, Indonesia \\ ${ }^{2}$ Language Center Universitas Muhammdiyah, Malang, Indonesia \\ \{1 peptia@ub.ac.id, ${ }^{2}$ safitrimega4@gmail.com $\}$
}

\begin{abstract}
This study attempts to present the correlation of students' perspective on the use of peer review towards students' writing performance in Essay Writing Class in English Education Program, Faculty of Cultural Studies, Universitas Brawijaya. The research subjects were 118 students of the third semester in academic year 2018/2019 taking Essay Writing Class. In collecting data, writing scores were used to represent students' writing performance and a questionnaire to know students' satisfaction with peer review sessions. The result of the study proved the correlation to be weak. The paper then discusses some factors that influence the usefulness of peer review session in helping students revising their drafts, such as students' background knowledge of the topic being written; students' scant proficiency in English; students' attitudes and time allotment in doing peer review session; and interpersonal relationship among students.
\end{abstract}

Keywords: Peer Review, Students', Perspective, Writing Performance, EFL Context.

\section{INTRODUCTION}

Since the growing awareness of pedagogy, students are now frequently exhibited to active collaborative learning and group activity. Automatically, constructivist becomes the umbrella for many classroom activities in which the major objective is derived to students' active learning [1], [2]. The movement of the constructivist suggests that the students should be able to interact in higher level of interaction in the classroom and take responsibility in their own learning. The students are required to develop their language skills by doing collaborative activities such as peer review, giving suggestion, and giving constructive comment on others' performance. These activities are expected to enhance students' ability by developing mutual communication as well [1]-[5]. Therefore, peer review becomes one of popular pedagogical activities among instructor in L2 writing classroom [6]. Further, over the past three decades there were abundance researchers used peer review in EFL context as their research topic [6][13].

However, some gaps in ESL/EFL peer review research were found including research design, context, grade level, and students' perspective in peer review session [14]. Most of previous studies used classroom-based research as the research design so that there was limited amount of correlational, (quasi-)experimental or meta-analysis studies. Further, a large number of ESL/EFL Chinese or Taiwanese speakers became the subjects of the studies. It is suggested then to expand the subjects to other EFL contexts in Asia. Those studies also were conducted mostly at tertiary level, leaved out graduate or university students. It was also 
suggested that further researchers can focus more on students' attitudes/perceptions of peer review session. Considering those gaps, this current study attempts to investigate students' perspective on the use of peer review towards students' writing performance in Essay Writing Class in English Language Education Program, Faculty of Cultural Studies, Universitas Brawijaya by posing a research hypothesis "There is a significant positive correlation between students' perspective on the use of peer review and students' writing performance".

Peer view or also known as peer feedback or peer response is defined as an activity in which students exchange draft one another in order to give and receive comment, suggestion, and revision from other students in the form of oral, written, or both oral and written. Generally, peer review is focused on some elements of writing. It covers global and local writing aspect [14]. The global aspect is given when the review is emphasized on the content, cohesion/coherence, and text organization, while the local aspect is assessed when the criticism focuses on the grammar, vocabulary, and punctuation. In addition, peer review can also be conducted using some media, such as face to face, commuter-medicated communication (CMC), asynchronous (e-mail), and synchronous (chats) [1], [9]. Therefore, by using the media and focused elements, peer review is stressed to get many feedbacks in order to improve the writing quality.

There is a common believe that writing is not only the product, but also the process, since then peer review is needed. Some previous researchers [9], [12], [12], [15] state that peer review involves thought, process of writing, and social cognitive aspect, and social constructionism. In the process of writing, peer review contributes in the beginning of writing process such as brainstorming and outlining and it also involves in the writing cycles that are started by brainstorming, outlining, drafting, and revising. Chang [14] also adds that peer review may also involve between drafting and final revision. Seen from the social cognitive and social constructionism which are pointed on the principle of the social constructed, peer review forms these aspects while students make an interaction in exchanging their works. In other words, peer review is beneficial for students writing and social facet.

Formerly, peer review is developed from sociocultural theory where the students interact throughout the writing process in order to create an illegible text [5], [16], [17]. In peer review, there will be mutual communication between students. It is also fruitful to establish sustained peer interaction and cooperation, shared decision making, and shared idea and responsibility to complete a task [3]. The benefits of peer review also appear in two conditions. The first benefit is helping the students to verbalize speculation on the language use and make negotiation meaning with their peer. These activities are involved in the peer assessment process when the students read the others' writing which is focused on the word choice, vocabulary items, or some expressions. That is why these activities make the students have better linguistics competence than involving in solely writing activity. In line with this, Scott \& Fuente [18] explain that working with peer allows the students to get linguistic resources more. It also helps the students to do scaffolding, so they can booster their cognitive aspect.

Second, peer assessment also encourages students to have better accuracy in their writing. Accuracy refers to the grammatical construction. According to Wigglesworth \& Storch [19] who conducted previous researches in peer assessment, found that students would have better sentence and passage structure in their written work. Vorobel \& Kim [4] also states that peer assessment helps the students in improving word choice and vocabulary matters. Further, it also encourages a good content of students writing as stated by Kostrova and Kulinich [20]. According to Yang [21] after receiving peer comment, students have better revision in 
meaning compared to getting comment form their teacher. In conclusion, peer review is useful to boost a good writing result.

In this present research, peer review session was divided into two activities. The first activity was done after the students finishing their first draft in each assignment both in group work and individual work. This activity involved scoring rubric focusing on the content, organization, and mechanics. After the students received the first draft review, they revised and created the second draft based on the first review result. The second activity was giving peer feedback in the form of written and oral feedback. This peer feedback was conducted when the students got review on their second draft and the focus of this activity was on the use of language.

Perception can be described as someone belief or attitudes toward particular aspect. According to Campbell [22], perception is described as an observation and a view about the observed aspect. Ahen [23] also mentions that perceptions can also be recognized as impression about someone or something. This perception matters in particular way because the perception affects the attitudes towards something. Therefore, if a teacher apply a technique, she/he needs tro know the students' perception since students become the object of the technique.

Previous researches showed various results on the students' perception on peer assessment. Chang [14] shows that students have moderate positive perception on peer review. They thought that peer assessment is linguistically and cognitively helpful. Besides, it is socially and affectively enjoyable for them. Ho \& Savigno [24] mentions the students' perception on this activity. They states that this activity helps the reviewer to enhance their awareness of the text quality, both in content and in the lexist. Moreover, De Guerrero \& Villamil [25] state that this activity encourages to establish social support from other students. Despite the advantages, when it goes to the deeper investigation, Chang [14] found that the students accept this activity as the complementary activity rather than replaces the teacher feedback. Other researches also shows that students prefer to have teacher feedback to their peer feedback. The students are hesitant with their peer ability to assess their writing. They still questioned with their peer competency and credibility of the feedback [13].

\section{RESEARCH METHOD}

This study was conducted by using correlational method. Starting from July to December 2018, 118 students of third semester students registered in Essay Writing class, 3 credits course. During 14 weeks of lecturer section, students are engaged in peer review session for three texts types; those are compare and contrast, cause and effect, and also argumentative text. Total, the students are exposed to six peer review sessions and six lecturer assessments. There were 2 assignments for group work in each type of the text and 3 assignments for individual group work for each text type.

More specifically, the peer review sessions consisted of peer review activity by using rubric focusing on the content, organization, and mechanics; and peer feedback in the form of both written and oral feedback. The peer review activities were done after the students finishing the first draft and focused on content, organization, and mechanics. While the peer feedback sessions were done after the students finishing the second draft and focused on language use. 


\section{a. Instruments}

Questionnaire was used as the instrument in this study to get clear vision on students' perspective towards peer review sessions. The questionnaire consists of 16 questions related to the students' satisfaction on peer review session. Questions number 1-6 used the following scale; strongly disagree, disagree, agree, and strongly agree. The other questions consisting questions number 7 up to 16 used never to always in 4 point scales (see appendix 1)

Another instrument was students' writing performance taken from students' score in writing 3 individual tasks. The students completed their task on difference text type including 2 expository essays (compare and contrast, and cause and effect) and also argumentative text essay. The researcher then used the students' mean score from those 3 assignments to represent students' writing performance in this study. Content, organization, diction, grammar, and mechanic became the criteria in evaluating the students' work.

\section{b. Statistical Analysis}

To measure the correlation between students' perspective on the use of peer review and students' writing performance, this research will employ Pearson Correlation technique which commonly called as Pearson product Moment Correlation. The correlation statistics was analyzed using SPSS resulting in correlation coefficient that display the degree of relationships and how closely there two variables.

The correlation coefficient is represented with $r$ and expressed as number between -1 and +1 . If the $r$ is -1 sign that the variables perform negative correlation and if the $r$ is +1 show that the variables are in positive correlation. When $r$ is 0 , it means that the variables are not correlated [26].

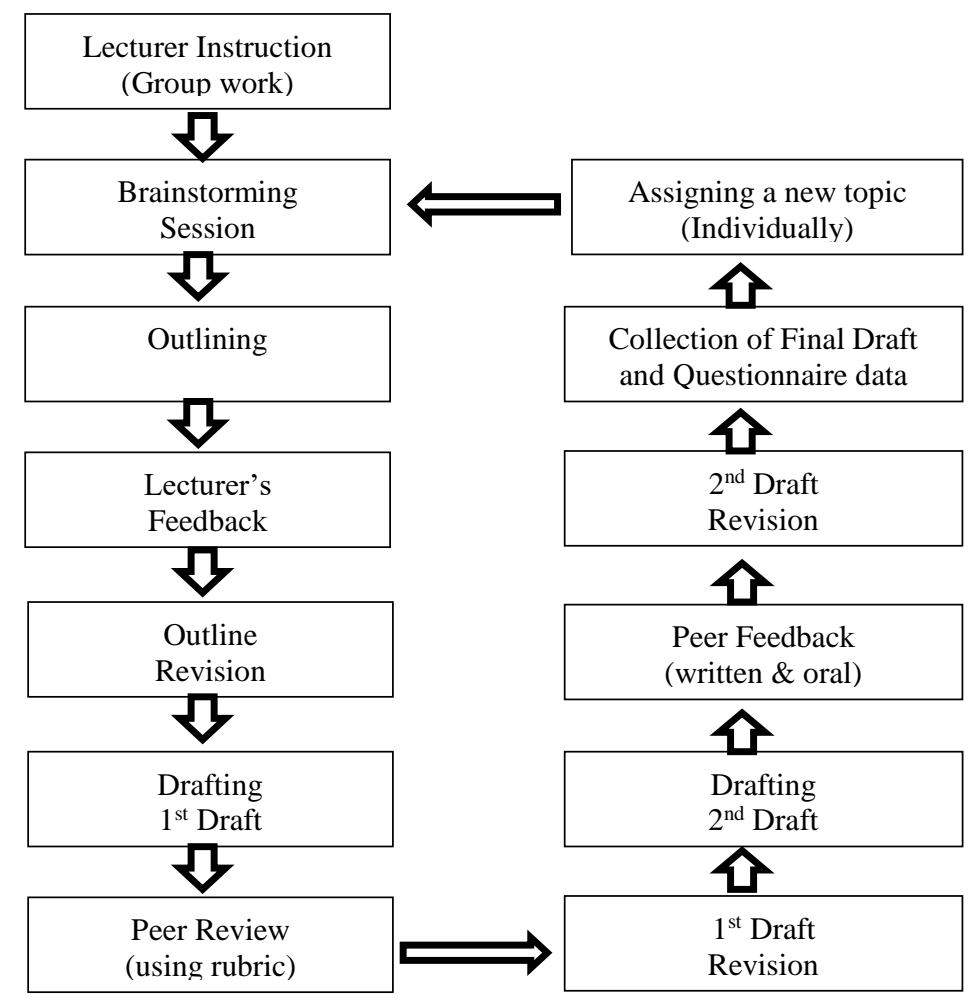

Figure 1. Flowchart of data collection 


\section{RESULT AND DISCUSSION}

This research employs 2 variables that consist of 1 independent variable and 1 dependent variable. Students' respond/satisfaction on peer review sessions (X) becomes the independent variable while students' writing performance $(\mathrm{Y})$ is used as the dependent variable. This research tried to reveal the correlational relationship between students' satisfaction on peer review sessions (X) to students' writing performance (Y). From the result of statistical computation using Pearson product Moment the researchers drawn an assumption: Correlation coefficient between students' satisfaction on peer review sessions (X) to students' writing performance $(\mathrm{Y})$ is 0.298 categorized as having weak positive correlation. While the $\mathrm{P}$ values $0.001>0.5$ shows that the correlation between two variables is insignificant.

This current study has addressed whether there is correlation between student's perspective on the usefulness of peer review session and the students' writing performance since many previous studies proved that student's has positive response on the use of peer review session in writing classes e.g. [4], [6], [8], [10]-[12], [15], [18], [19], etc.). However, the finding in this current research shows that correlation between students' respond on the use of peer review and students' writing performance is having weak positive correlation. It means that the highest students' score in writing is not followed by high positive response from students.

The reasons underlying this result may lie from some factors such as the students' score being computed in SPSS and students' difference proficiency in English. Related to the students' score in which used to show the students' writing performance, the researcher use students' score from the final draft of each tasks. Most of students' score were good, since it has been revised and edited several time in peer review sessions, self-assessment, and also teachers' feedback sessions. As a result, the students' score were not varied significantly. Further, the students with high proficiency in English tend to have low responds towards the usefulness of peer review sessions since they did not regard the feedback from peer review session as effective as teachers' feedback.

This research finding is in line with Wang [13], there are some factors that influence the usefulness of peer review session in helping students revising their drafts, such as students' background knowledge of the topic being written; students' scant proficiency in English; students' attitudes and time allotment in doing peer review session; and interpersonal relationship among students.

\section{CONCLUSIONS}

This research has justified the usefulness of peer review session on students' writing performance from students' point of view. It was proven that the students' responses on the usefulness of peer review session indeed are affected by both internal factors such as students' proficiency in English and also external factor such as teachers' feedback. Different proficiency in English between student as a writer and student as a peer reviewer lead to different response on the usefulness of peer review session. Students as a writer with high proficiency in English tend to give negative response towards the usefulness of peer review session. On the other hand, Students as a writer with medium or low proficiency in English have different perspective. They feel that peer review sessions were very useful for them in improving their writing. Further, factors influence the students writing performance are varied 
during the writing process since the students did some revision and editing not only based on peer review session but also on self-assessment session and teachers feedback session.

\section{REFERENCES}

[1] Y.-J. Lan, Y. Sung, and K.-E. Chang, "A mobile-device-supported peer-assisted learning system for collaborative early EFL reading," Lang. Learn. Technol., vol. 11, no. 3, pp. 130-151, 2007.

[2] T. Locke and M. Johnston, "Developing an individual and collective self-efficacy scale for the teaching of writing in high schools," Assess. Writ., vol. 28, pp. 1-14, Apr. 2016.

[3] K. McDonough, J. De Vleeschauwer, and W. Crawford, "Comparing the quality of collaborative writing, collaborative prewriting, and individual texts in a Thai EFL context," System, vol. 74, pp. 109-120, Jun. 2018.

[4] O. Vorobel and D. Kim, "Adolescent ELLs' collaborative writing practices in face-toface and online contexts: From perceptions to action," System, vol. 65, pp. 78-89, Apr. 2017.

[5] M. Zhang, "Collaborative writing in the EFL classroom: The effects of L1 and L2 use," System, vol. 76, pp. 1-12, Aug. 2018.

[6] S. Yu and G. Hu, "Understanding university students' peer feedback practices in EFL writing: Insights from a case study," Assess. Writ., vol. 33, pp. 25-35, Jul. 2017.

[7] R. Ruegg, "The relative effects of peer and teacher feedback on improvement in EFL students' writing ability," Linguist. Educ., vol. 29, pp. 73-82, Apr. 2015.

[8] C. Y. Chang, "Teacher modeling on EFL reviewers' audience-aware feedback and affectivity in L2 peer review," Assess. Writ., vol. 25, pp. 2-21, Jul. 2015.

[9] C.-F. Chang, "Peer Review via Three Modes in an EFL Writing Course," Comput. Compos., vol. 29, no. 1, pp. 63-78, Mar. 2012.

[10] S. Yu and I. Lee, "An analysis of Chinese EFL students' use of first and second language in peer feedback of L2 writing," System, vol. 47, pp. 28-38, Dec. 2014.

[11] H.-T. Min, "Effect of teacher modeling and feedback on EFL students' peer review skills in peer review training," J. Second Lang. Writ., vol. 31, pp. 43-57, 2016.

[12] H. Zhao, "New insights into the process of peer review for EFL writing: A processoriented socio-cultural perspective," Learn. Instr., vol. 58, pp. 263-273, Dec. 2018.

[13] W. Wang, "Students' perceptions of rubric-referenced peer feedback on EFL writing: A longitudinal inquiry," Assess. Writ., vol. 19, pp. 80-96, Jan. 2014.

[14] Y. Chang, "Two decades of research in L2 peer review.," J. Writ. Res., vol. 8, no. 1, 2016.

[15] R. Ruegg, "The relative effects of peer and teacher feedback on improvement in EFL students' writing ability," Linguist. Educ., vol. 29, pp. 73-82, Apr. 2015.

[16] C. Kalina and K. C. Powell, "Cognitive and social constructivism: Developing tools for an effective classroom," Education, vol. 130, no. 2, pp. 241-250, 2009.

[17] A. Ahmed and D. Myhill, "The impact of the socio-cultural context on L2 English writing of Egyptian university students," Learn. Cult. Soc. Interact., vol. 11, pp. 117 129, Dec. 2016.

[18] V. M. Scott and M. J. D. L. FUENTE, "What's the problem? L2 learners' use of the L1 during consciousness-raising, form-focused tasks," Mod. Lang. J., vol. 92, no. 1, pp. 100-113, 2008. 
[19] G. Wigglesworth and N. Storch, "Pair versus individual writing: Effects on fluency, complexity and accuracy," Lang. Test., vol. 26, no. 3, pp. 445-466, Jun. 2009.

[20] O. Kostrova and M. Kulinich, "Text Genre 'Academic Writing': Intercultural View," Procedia - Soc. Behav. Sci., vol. 206, pp. 85-89, Oct. 2015.

[21] H.-C. Yang, "Describing and interpreting graphs: The relationships between undergraduate writer characteristics and academic graph writing performance," Assess. Writ., vol. 28, pp. 28-42, Apr. 2016.

[22] D. T. Campbell, "Stereotypes and the perception of group differences.," Am. Psychol., vol. 22, no. 10, pp. 817-829, 1967.

[23] J. A. Ahen, Students' Perception Towards English for Self Expression, Unpublished Thesis. Sarawak: University Malaysia Sarawak, 2009.

[24] M. Ho and S. J. Savignon, "Face-to-face and Computer-mediated Peer Review in EFL Writing," CALICO J., vol. 24, no. 2, pp. 269-290, Jan. 2013.

[25] M. C. M. De Guerrero and O. S. Villamil, "Activating the ZPD: Mutual Scaffolding in L2 Peer Revision,” Mod. Lang. J., vol. 84, no. 1, pp. 51-68, Mar. 2000.

[26] D. Ari, L. C. Jacobs, C. Sorensen, and A. Razavieh, Introduction to Research in Education, 8th ed. USA: Wadsworth, 2010.

[27] J. Lu, "Student Attitudes towards Peer Review in University Level English as a Second Language Writing Classes," 2016. 